\title{
Inventarisasi Jenis Gulma di Areal Perkebunan Karet (Hevea brasiliensis) Pada Ketinggian Tempat Yang Berbeda di Negeri Liang Kecamatan Teluk Elpaputih Kabupaten Maluku Tengah
}

\author{
Inventory of Weed Types in Rubber Plantation Areas (Hevea brasiliensis) at Different \\ Altitudes in the Land of Liang, Teluk Elpaputih District, Central Maluku Regency
}

\section{Dilyan Nurzharisa Ramlan ${ }^{1}$, Johan Riry ${ }^{2, *}$, Vilma Laurien Tanasale ${ }^{2}$}

\author{
${ }^{1}$ Program Studi Agroteknologi, Jurusan Budidaya Pertanian, Fakultas Pertanian, Universitas Pattimura Ambon, \\ J1. Ir. M. Putuhena, Kampus Poka, Ambon 97233 \\ ${ }^{2}$ Jurusan Budidaya Pertanian, Fakultas Pertanian, Universitas Pattimura Ambon, Jl. Ir. M. Putuhena, Kampus \\ Poka, Ambon 97233 \\ *E-mail Penulis Korespondensi: johanriry@yahoo.com
}

\begin{abstract}
The purpose of this study was to analyze the types of dominant weeds in rubber plantation areas at altitudes of 4 $m$ above sea level (asl) and $104 \mathrm{~m}$ asl and to find differences in the types of weeds in the rubber plantation areas at an altitude of $4 \mathrm{~m}$ asl and $104 \mathrm{~m}$ asl. This research conducted in Negeri Liang, Teluk Elpaputih District, Central Maluku Regency. This research used a "weed survey" method to collect data by direct observation in the field. This research was conducted by analyzing weed types using the quadratic method by purposive sampling with a sample plot size of 1 $m \times 1 \mathrm{~m}$. From this study, it was found that there were 20 weed species from 14 families, with details of 11 species of full leaf weeds, 3 species of grasses, 3 species of sedges, in rubber plantation habitat in Liang Village, Teluk Elpaputih District, Central Maluku Regency.
\end{abstract}

Keywords: plantation altitude, rubber plants, weeds

\section{ABSTRAK}

Tujuan penelitian ini adalah untuk menganalisis jenis-jenis gulma dominan di areal perkebunan karet pada ketinggian $4 \mathrm{~m}$ dpl dan $104 \mathrm{~m}$ dpl dan untuk menemukan perbedaan jenis-jenis gulma di areal perkebunan karet pada ketinggian $4 \mathrm{~m}$ dpl dan $104 \mathrm{~m}$ dpl. Penelitian ini dilaksanakan di Negeri Liang Kecamatan Teluk Elpaputih Kabupaten Maluku Tengah. Dengan menggunakan metode "survey gulma" untuk mengumpulkan data dengan pengamatan langsung di lapangan. Dengan melakukan analisis jenis gulma digunakan metode kuadrat secara purposive sampling dengan petak sampel berukuran $1 \mathrm{~m} \times 1 \mathrm{~m}$. Penelitian ini di peroleh terdapat 20 jenis gulma 14 famili, dengan rincian gulma daun lebar 11 jenis, rerumputan 3 jenis, tekian 3 jenis, dan pakisan 3 jenis pada habitat perkebunan karet di Negeri Liang Kecamatan Teluk Elpaputih Kabupaten Maluku Tengah.

Kata kunci: gulma, ketinggian tempat yang berbeda, tanaman karet

\section{PENDAHULUAN}

Tanaman karet merupakan salah satu komoditas pertanian di Indonesia sebagai sumber devisa dan banyak menyerap tenaga kerja, sebagai komoditas penghasil getah, tanaman karet banyak dimanfaatkan secara luas baik dalam skala industri maupun untuk kepentingan masyarakat. Tanaman karet bermanfaat dalam pembuatan karet getah yang dihasilkan dari tanaman karet menjadi bahan utama dalam pembuatan karet. Tanaman karet juga dapat mengurangi emisi rumah kaca. Perkebunan karet di Indonesia merupakan perkebunan terluas didunia mencapai 3 juta hektar lebih.
Di Maluku Tengah, karet sebagai komoditas ekspor yang penting tetapi perkebunan ini juga tidak terlepas dari masalah-masalah pengelolaan terutama pengelolaan terhadap tanaman pengganggu (gulma).

Gulma merupakan tumbuhan yang tumbuh di sekitar tanaman yang dibudidayakan dan kehadirannya tidak diinginkan karena dapat merugikan tanaman yang dibudidayakan (Prayogo et al., 2017). Gulma merupakan salah satu organisme pengganggu tanaman yang menghambat pertumbuhan, perkembangan dan produktivitas tanaman. Kehadiran gulma di sekitar tanaman budidaya tidak dapat dihindarkan, terutama jika lahan tersebut ditelantarkan (Palijama et al., 2012; 
Sastrautomo, 1998). Kehadiran gulma di suatu areal pertanaman secara umum memberikan pengaruh negatif terhadap tanaman, karena gulma memiliki daya kompetitif yang tinggi sehingga memungkinkan terjadinya persaingan cahaya, $\mathrm{CO}_{2}$, air, unsur hara, ruang tumbuh yang digunakan secara bersamaan. Gulma dapat merugikan tanaman yang dibudidayakan karena disebabkan oleh adanya persaingan antara tanaman utama sehingga mengurangi kemampuan berproduksi, terjadi persaingan dalam pengambilan air, unsur-unsur hara dari tanah, cahaya dan ruang lingkup, pengotoran kualitas produksi pertanian, misalnya pengotoran benih oleh biji-biji gulma. Gulma juga dapat mengeluarkan suatu zat yang sifatnya beracun yang biasanya dikenal dengan nama alelopati, sehingga merusak pertumbuhan tanaman dan gangguan kelancaran pekerjaan para petani (Taulu, 2014).

Persaingan antara tanaman dan gulma dapat mengakibatkan pertumbuhan tanaman budidaya tertekan, menghambat kelancaran aktivitas pertanian, estetika lingkungan tidak nyaman dan meningkatkan biaya pemeliharaan (Kilkoda et al., 2015; Ngatiman dan Fajri, 2018). Kemampuan tanaman dalam bersaing dengan gulma ditentukan oleh spesies gulma, kepadatan gulma, lama persaingan, cara budidaya dan varietas yang ditanam, serta tingkat kesuburan tanah. Perbedaan spesies akan menentukan kemampuan bersaing karena perbedaan sistem fotosintesis, kondisi perakaran dan morfologinya. Kelembaban atau kerapatan populasi gulma menentukan persaingan dan penurunan produksi tanaman. Gulma yang muncul atau berkecambah lebih dulu atau bersamaan dengan tanaman budidaya menyebabkan penurunan pertumbuhan dan hasil panen tanaman tersebut. Persaingan gulma pada awal pertumbuhan akan mengurangi kuantitas hasil, sedangkan persaingan dan gangguan gulma menjelang panen berpengaruh besar terhadap kualitas hasil. Perbedaan cara penanaman, laju pertumbuhan, umur varietas yang ditanam dan tingkat ketersediaan unsur hara juga akan menentukan besarnya persaingan gulma dengan tanaman. Persaingan menyebabkan terjadinya penurunan aktivitas pertumbuhan.

Provinsi Maluku merupakan salah satu provinsi yang secara geografis merupakan daerah kepulauan yang memiliki daratan yang cukup luas dan cocok bagi pertanian. Salah satu sumber daya alam Maluku yang memiliki potensi untuk dikembangkan adalah sub sektor perkebunan. Tanaman karet merupakan salah satu komoditi perkebunan yang menduduki posisi cukup penting sebagai sumber devisa non migas di Indonesia.

Karet merupakan salah satu tanaman perkebunan yang mengalami penurunan produksi di Kabupaten Maluku Tengah. Produksi tanaman karet tidak dapat dipertahankan dan cenderung mengalami penurunan. Berdasarkan data PTPN XIV tahun 2014 dengan luasan areal komoditi tanaman karet sebesar 4,632 Ha dengan produksi sebesar 3.910 tahun 2013 dan mengalami penurunan menjadi 2,538 pada tahun 2014 .

Tanaman karet yang ditanam di Negeri Liang Awaya berada pada ketinggian yang berbeda ketinggian suatu tempat sangat menentukan jenis organisme yang hidup ditempat tersebut. Daerah dengan ketinggian yang berbeda akan memiliki kondisi fisik yang berbeda juga, oleh sebab itu gulma yang terdapat di dataran tinggi relatif berbeda dengan gulma didaerah dataran rendah (Istiawan dan Kastono, 2018; Nurnasari dan Djumali, 2010; Syawal, 2011).

Salah satu penyebab menurunnya produksi karet pada areal perkebunan di Kabupaten Maluku Tengah adalah gulma. Menurut data dari PTPN XIV 2014, tanaman karet yang berada di Negeri Liang Awaya mengalami penurunan dari tahun ke tahun disebabkan oleh adanya kehadiran gulma pada setiap ketinggian tempat yang berbeda. Untuk itu perlu adanya Inventarisasi Jenis Gulma Di Areal Perkebunan Karet Pada Ketinggian Yang Berbeda Di Negeri Liang Awaya Kecamatan Teluk Elpaputih Kabupaten Maluku Tengah.

Penelitian ini bertujuan untuk menganalisis jenis gulma dominan di areal perkebunan karet pada ketinggian tempat yang berbeda dan untuk menemukan jenis-jenis gulma perkebunan karet pada ketinggian tempat yang berbeda

\section{METODE PENELITIAN}

\section{Tempat dan Waktu}

Penelitian ini dilaksanakan di Negeri Liang Awaya Kecamatan Teluk Elpaputih Kabupaten Maluku Tengah. Penelitian ini berlangsung di lapangan pada bulan September sampai dengan November 2018.

\section{Bahan dan Alat}

Bahan yang digunakan dalam penelitian ini adalah jenis alami gulma pada areal perkebunan karet dan tinggi tempat yang berbeda pada ketinggian $4 \mathrm{~m} \mathrm{dpl}$ dan $104 \mathrm{~m}$ dpl, label, kantong plastik, amplop coklat.

Alat yang digunakan dalam penelitian ini adalah kamera, soil tester, frame ukuran $1 \mathrm{~m} \times 1 \mathrm{~m}$, cutter, oven, altimeter, thermometer, buku pedoman identifikasi, label pengamatan, alat tulis menulis.

\section{Metode Penelitian}

Penelitian ini menggunakan metode "survey gulma" untuk mengumpulkan data dengan pengamatan langsung di lapangan. Vegetasi dianalisis menggunakan metode kuadrat secara purposive sampling dengan petak sampel berukuran $1 \mathrm{~m} \times 1 \mathrm{~m}$.

\section{Pelaksanaan Penelitian}

Pengambilan sampel pada areal perkebunan karet di Desa Liang Awaya dilakukan di setiap areal dengan ketinggian yang berbeda yakni pada ketinggian $4 \mathrm{~m} \mathrm{dpl}$ dan $104 \mathrm{~m}$ dpl. Sampel diambil pada masing-masing areal perkebunan karet dengan cara menggunakan tali yang ditarik pada areal perkebunan dengan ukuran 100 $\mathrm{m} \times 100 \mathrm{~m}$ kemudian untuk pengambilan sampel di 
ukur dengan jarak $25 \mathrm{~m}$ per titik pengamatan sehingga diperoleh 25 sampel pengamatan per ketinggian tempat sehingga diperoleh 50 sampel pengamatan pada ketinggian tempat yang berbeda.

Gulma yang terdapat dalam petak sampel dipotong dekat permukaan tanah, dimasukkan kedalam kantong plastik, di identifikasi jenisnya kemudian dibungkus dengan amplop coklat yang telah diberi label sesuai dengan petak pengamatan. Dikeringkan dalam oven sampai berat kering yang konstan.

Pengukuran $\mathrm{pH}$ tanah dan kelembaban tanah diukur menggunakan soil tester, pengukuran dilakukan tiga kali pada setiap areal dengan ketinggian tempat yang berbeda. Pengukuran suhu udara diukur menggunakan termometer, dilakukan pada pagi, siang, dan sore hari.

\section{Teknik Pengumpulan Data}

Teknik pengumpulan data merupakan langkah yang paling utama dalam proses penelitian, karena tujuan utama dari penelitian adalah mendapatkan data. Kegiatan pengumpulan data ada yang bersifat kualitatif dan kuantitatif.

Data yang dikumpulkan dari penelitian ini adalah data gulma. Data gulma yang bersifat kualitatif yaitu daur hidup, penyebaran, periodisitas, dan vitalitas, sedangkan data gulma yang bersifat kuantitatif yaitu kerapatan frekuensi, kehadiran gulma, dan biomassa jenis gulma.

Data yang diperlukan dalam penelitian ini juga terdiri atas data primer dan data sekunder. Data primer di peroleh melalui pencatatan jenis-jenis gulma tentang frekuensi, kerapatan, dan biomassa (berat kering) setiap petak sampel, sedangkan untuk data sekunder diperoleh dari data umum wilayah (keadaan umum lokasi) dan data iklim (curah hujan) untuk 5 tahun terakhir sebagai bahan pembanding berupa parameter diukur langsung di lapangan seperti $\mathrm{pH}$ tanah, kelembaban tanah, dan suhu pada ketinggian $4 \mathrm{~m}$ dpl dan $104 \mathrm{~m} \mathrm{dpl}$.

Pengukuran $\mathrm{pH}$ dan kelembaban tanah dilakukan untuk setiap titik pengamatan pada ketinggian $4 \mathrm{~m} \mathrm{dpl}$ dan $104 \mathrm{~m}$ dpl.

Pengukuran suhu dilakukan pada tanaman menghasilkan dengan ketinggian $4 \mathrm{~m}$ dpl dan $104 \mathrm{~m} \mathrm{dpl}$ untuk setiap titik pengamatan. Pengukuran suhu dilakukan menggunakan alat thermometer.

\section{Analisis Data}

Data yang terkumpul kemudian dianalisis secara deskripsi kuantitatif. Untuk menghitung kerapatan dan frekuensi serta dominasi gulma, maka digunakan rumus menurut (Tjitrosoedirdjo et al., 1984) sebagai berikut:

\begin{tabular}{ccc}
$\begin{array}{c}\text { Kerapatan } \\
\text { Relatif }(\mathrm{KM})\end{array}$ & $\begin{array}{c}\text { Jumlah individu gulma dalam satu } \\
\text { spesies }\end{array}$ \\
$\begin{array}{c}\text { Kerapatan } \\
\text { Relatif }(\mathrm{KR})\end{array}$ & $=\begin{array}{c}\text { Kerapatan mutlak } \\
\text { spesies tertentu }\end{array}$ & $\times 100 \%$ \\
\hline
\end{tabular}

\begin{tabular}{cc}
\hline & $\begin{array}{c}\text { Jumlah kerapatan } \\
\text { mutlak semua jenis }\end{array}$ \\
\hline $\begin{array}{c}\text { Frekuensi } \\
\text { Mutlak (FM) }\end{array}$ & $\begin{array}{c}\text { Jumlah petak sampel yang memuat } \\
\text { satu jenis gulma }\end{array}$ \\
Frekuensi & $=\begin{array}{c}\text { Frekunesi mutlak } \\
\text { satu spesies }\end{array}$ \\
Relatif $(\mathrm{KR})$ & $\begin{array}{c}\text { Jumlah frekuensi } \\
\text { semua jenis }\end{array}$
\end{tabular}

Biomassa Mutlak (BM) $=$ Bobot kering setiap spesies gulma

$\begin{gathered}\text { Biomassa } \\ \text { Relatif }(\mathrm{BR})\end{gathered}=\frac{\begin{array}{c}\text { Biomassa mutlak } \\ \text { spesies tertentu }\end{array}}{\begin{array}{c}\text { Jumlah biomassa } \\ \text { mutlak semua jenis }\end{array}} \times 100 \%$

$\begin{aligned} & \text { Summed Domination } \\ & \text { Ratio }(\mathrm{SDR})\end{aligned}=\frac{\mathrm{KR}+\mathrm{FR}+\mathrm{BR}}{3}$

Perbandingan dua komunitas vegetasi gulma dalakukan dengan digunakan rumus yang dikembangkan oleh Sukman (2012) yaitu:

$$
\mathrm{C}=\frac{2 \mathrm{~W}}{\mathrm{a}+\mathrm{b}} \times 100 \%
$$

Keterangan: $\mathrm{C}=$ Koefisien komunitas gulma; $\mathrm{W}=$ Jumlah SDR terendah untuk jenis dari masing-masing komunitas; $a=$ Jumlah SDR semua jenis gulma pada komunitas $\mathrm{A} ; \mathrm{b}=$ Jumlah SDR semua jenis gulma pada komunitas B.

Berdasarkan nilai $\mathrm{C}$ diantara ketinggian tempat yang di bandingkan pada ketinggian $4 \mathrm{~m}$ dpl dan $104 \mathrm{~m}$ dpl. Jika nilai C lebih besar dari $70 \%$ maka komunitas gulma antara beberapa ketinggian tempat tersebut sama maka cara pengendalian gulma yang di anjurkan juga sama dan apabila nilai C kurang dari $70 \%$ maka komunitas gulma antara beberapa ketinggian tersebut juga berbeda sehingga cara pengendalian gulma yang dianjurkan berbeda sesuai dengan lokasi dan ketinggian tempat masing-masing.

\section{HASIL DAN PEMBAHASAN}

\section{Keadaan Umum Lokasi Negeri Liang}

Daerah penelitian terletak di Negeri Liang, Kecamatan Teluk Elpa Putih, Kabupaten Maluku Tengah. Berdasarkan administrasi pemerintahan yang tercantum dalam peraturan Menteri Dalam Negeri No/25 Tahun 2007 tentang Pedoman Umum Tata Cara Pelaporan dan Penanggung Jawaban Penyelenggaraan Pemerintah Negeri, maka Negeri Liang memiliki batasbatas wilayah yakni Sebelah Utara berbatasan dengan Kali Suluden (Dusun Rumahlait), Sebelah Selatan berbatasan dengan Laut Kali Mala, Sebelah Barat 
berbatasan dengan Kali Mala, dan Sebelah Timur berbatasan dengan Laut.

Negeri Liang memiliki topografi wilayah yang terdiri dari daratan, pesisir, dan bukit dengan ketinggian 0-300 m dari permukaan laut. Negeri Liang terletak di Kecamatan Teluk Elpaputih Kabupaten Maluku Tengah dengan luas areal 10.000 ha. Luas areal yang digunakan untuk perkebunan karet yaitu 4.667 ha dan luas areal yang didiami oleh penduduk lokal maupun pendatang adalah seluas 11,5 ha dari rencana ruang pemukiman masyarakat seluas 27,5 ha dengan jumlah penduduk 250 KK dan jumlah jiwa 1998 orang. Wilayah Negeri Liang merupakan 1 dari 4 Negeri yang berada di Kecamatan Teluk Elpaputih Kabupaten Maluku Tengah Yakni Negeri Sahulau, Negeri Tananahu, dan Negeri Waraka.

\section{Iklim Daerah Penelitian}

Dilihat dari letaknya, daerah penelitian berada pada daerah tropis dengan curah hujan rendah. Selain itu, daerah penelitian yang termasuk dalam tipe iklim musim dimana terjadi pergantian musim sebagaimana yang berlaku di daerah lainnya pada daerah Provinsi Maluku yaitu Musim Kemarau dan Musim Hujan.

Menurut Oldeman (1975), dikatakan bulan basah terjadi bila curah hujan lebih dari $200 \mathrm{~mm} /$ bulan, Bulan lembab terjadi bila curah hujan antara 100-200 $\mathrm{mm} / \mathrm{bulan}$, dan Bulan kering terjadi bila curah hujan kurang dari $100 \mathrm{~mm} /$ bulan.

\section{Keadaan Fisik Lahan}

Berdasarkan pengamatan di lapangan, Negeri Liang pada ketinggian dibawah 100 memiliki tekstur tanah lempung berpasir dengan warna tanah merah kuning dan pada ketinggian diatas 100 memiliki tekstur tanah lempung dengan warna tanah kelabu hingga hitam. Jenis tanah di Negeri Liang pada ketinggian dibawah 100 yaitu Podsolik dengan $\mathrm{pH}$ tanah 6,8 dan pada ketinggian diatas 100 yaitu Grumusol dengan $\mathrm{pH}$ tanah 7,2.

\section{Topografi Bentuk Wilayah}

Topografi adalah salah satu karakteristik lahan yang menggambarkan konfigurasi permukaan lahan dan menunjukkan kemiringan lereng. Berdasarkan hasil observasi lapangan, maka daerah penelitian terletak pada ketinggian 4-104 m dpl.

\section{Penggunaan Lahan}

Hasil observasi lapangan menunjukkan bahwa penggunaan kedua lahan di daerah penelitian merupakan kebun tunggal.

\section{Komposisi dan Struktur Vegetasi Gulma}

Dari hasil pengamatan gulma di Negeri Liang menunjukkan bahwa di areal perkebunan karet terdapat 11 jenis gulma dari 8 suku pada ketinggian tempat $4 \mathrm{~m}$ dpl dan 14 jenis gulma dari 13 suku pada ketinggian 104 $\mathrm{m}$ dpl serta 20 jenis gulma yang dikelompokkan atas 11 gulma daun lebar, 3 gulma rerumputan, 3 gulma tekian, dan 3 gulma pakisan.

Berdasarkan jumlah nilai dominan (SDR) maka pada ketinggian tempat $4 \mathrm{~m}$ dpl yang memiliki nilai tertinggi adalah jenis gulma Clidemia hirta $15,36 \%$ dari suku Melastomataceae. Tumbuhan ini dinyatakan sebagai gulma dominan. Urutan kedua yaitu Cyperus kyllingia 11,39 persen dari suku Cyperaceae. Urutan ketiga yaitu Chromolaena odorata 9,86 persen dari suku Asteraceae. Urutan keempat yaitu Cyclosorus aridus 9,79 persen dari suku Thelypteridaceae. Urutan Kelima yaitu Mimosa pudica 9,51 persen dari suku Acanthaceae. Pada areal perkebunan karet dengan ketinggian $4 \mathrm{~m}$ dpl terdapat 3 jenis gulma daun lebar (broad leaf) dari 3 Suku, 3 jenis gulma rerumputan (grasses) dari 1 suku, 3 jenis gulma tekian (cyperaceae) dari 1 suku dan 2 jenis gulma pakisan (fern) dari 2 suku.

Berdasarkan morfologinya, gulma daun lear (broad leaf) memiliki nilai SDR tertinggi sebesar 34,73 persen, gulma tekian Sebesar 27,36 persen, gulma pakisan sebesar 18,96 persen, dan gulma rerumputan sebesar 18,93 persen. Sehingga, dari hasil nilai SDR maka gulma daun lebar (broad leaf) merupakan gulma dominan.

Tabel 1. Data curah hujan tahun 2013-2017 (mm)

\begin{tabular}{lccccc}
\hline Tahun & $\mathbf{2 0 1 3}$ & $\mathbf{2 0 1 4}$ & $\mathbf{2 0 1 5}$ & $\mathbf{2 0 1 6}$ & $\mathbf{2 0 1 7}$ \\
\hline Januari & 252,1 & 242 & 160 & 110 & 284 \\
Februari & 194,8 & 171 & 196 & 46 & 84 \\
Maret & 77,6 & 60 & 120 & 344 & 143 \\
April & 166,9 & 154 & 180 & 101 & 129 \\
Mei & 395,1 & 417 & 217 & 155 & 751 \\
Juni & 359,6 & 383 & 560 & 743 & 1430 \\
Juli & 1923,1 & 226 & 114 & 350 & 4046 \\
Agustus & 629 & 498 & 103 & 363 & 501 \\
September & 360 & 117 & 4 & 185 & 180 \\
Oktober & 129 & 129 & 24 & 37 & 189 \\
November & 91 & 31 & 25 & 119 & 176 \\
Desember & 220 & 135 & & & \\
\hline
\end{tabular}




\begin{tabular}{llllll}
\hline Jumlah & 4798,2 & 2563 & 1716 & 2637 & 5433 \\
\hline
\end{tabular}

Sumber: BMKG Pattimura Laha-Ambon 2018.

Tabel 2. Nilai SDR tanaman karet di daerah penelitian pada ketinggian $4 \mathrm{~m}$ dpl dan $104 \mathrm{~m} \mathrm{dpl}$

\begin{tabular}{|c|c|c|c|c|c|}
\hline \multirow[t]{2}{*}{$\mathrm{NO}$} & \multirow[t]{2}{*}{ JENIS GULMA } & \multirow{2}{*}{$\begin{array}{c}\text { TIPE } \\
\text { GULMA }\end{array}$} & \multirow{2}{*}{$\begin{array}{l}\text { DAUR } \\
\text { HIDUP } \\
\text { GULMA } \\
\end{array}$} & \multicolumn{2}{|c|}{ SDR } \\
\hline & & & & $4 \mathrm{M} \mathrm{DPL}$ & $104 \mathrm{M} \mathrm{DPL}$ \\
\hline 1 & $\begin{array}{l}\text { MELASTOMATACEAE } \\
\text { Clidemia hirta } \\
\text { ACANTHACEAE }\end{array}$ & Daun Lebar & Tahunan & 15,36 & 7,97 \\
\hline 2 & $\begin{array}{l}\text { Mimosa pudica } \\
\text { LOMARIPSIDACEAE }\end{array}$ & Daun Lebar & Tahunan & 9,51 & 4,97 \\
\hline 3 & $\begin{array}{l}\text { Nephrolepis biserrata } \\
\text { THELYPTERIDACEAE }\end{array}$ & Pakisan & Tahunan & 9,17 & 7,54 \\
\hline 4 & $\begin{array}{l}\text { Cyclosorus aridus } \\
\text { CYPERACEAE }\end{array}$ & Pakisan & Tahunan & 9,79 & 11,70 \\
\hline 5 & Cyperus kyllingia & Tekian & Tahunan & 11,39 & 0 \\
\hline 6 & Scleria sumatrensis & Tekian & Tahunan & 8,33 & 6,01 \\
\hline 7 & $\begin{array}{l}\text { Cyperus rotundus } \\
\text { ASTERACEAE }\end{array}$ & Tekian & Tahunan & 7,64 & 0 \\
\hline 8 & Chromlaena odorata & Daun Lebar & Tahunan & 9,86 & 0 \\
\hline 9 & Agerantum conyzoides & Daun Lebar & Semusim & 0 & 4,91 \\
\hline 10 & $\begin{array}{l}\text { Wedelia trilobata } \\
\text { POACEAE }\end{array}$ & Daun Lebar & Tahunan & 0 & 8,64 \\
\hline 11 & Eleusine indica & Rerumputan & Semusim & 8,30 & 0 \\
\hline 12 & Paspalum conjugatum & Rerumputan & Tahunan & 5,85 & 6,44 \\
\hline 13 & $\begin{array}{l}\text { Imperata cylindrica } \\
\text { PHYLLANTHACEAE }\end{array}$ & Rerumputan & Tahunan & 4,78 & 0 \\
\hline 14 & $\begin{array}{l}\text { Phyllanthus niruri } \\
\text { LAMIACEAE }\end{array}$ & Daun Lebar & Semusim & 0 & 6,56 \\
\hline 15 & $\begin{array}{l}\text { Hyptis rhomboidea } \\
\text { PIPERACEAE }\end{array}$ & Daun Lebar & Tahunan & 0 & 5,12 \\
\hline 16 & $\begin{array}{l}\text { Piper betle } \\
\text { FABACEAE }\end{array}$ & Daun Lebar & Tahunan & 0 & 4,44 \\
\hline 17 & $\begin{array}{l}\text { Centrosema pubescens } \\
\text { RUBIACEAE }\end{array}$ & Daun Lebar & Tahunan & 0 & 7,98 \\
\hline 18 & $\begin{array}{l}\text { Borreria laevis } \\
\text { SCHIZEAACEAE }\end{array}$ & Daun Lebar & Tahunan & 0 & 4,44 \\
\hline 19 & $\begin{array}{l}\text { Lygodium longifolium } \\
\text { SELAGINELLACEAE }\end{array}$ & Pakisan & Semusim & 0 & 4,29 \\
\hline 20 & Selaginella doederleinii hieron & Daun Lebar & Tahunan & 0 & 8,96 \\
\hline
\end{tabular}

Berdasarkan daur hidupnya, gulma tahunan memiliki nilai SDR 91,68 Persen dengan jumlah gulma sebanyak 10 jenis gulma, sedangkan gulma semusim memiliki nilai SDR 8,30 Persen dengan jumlah gulma sebanyak 1 Jenis gulma.

Pada areal perkebunan karet dengan ketinggian $104 \mathrm{~m}$ dpl yang memiliki nilai SDR tertinggi adalah Cyclosorus aridus 12,32 persen dari suku Thelypteridaceae. Urutan kedua yaitu Selaginella doederleinii hieron 9,41 persen dari suku Selaginellaceae, dan urutan ketiga yaitu Wedelia trilobata 9,09 persen dari suku Asteraceae. Urutan keempat yaitu Centrosema pubescens 7,98 persen dari suku Fabaceae. Urutan kelima yaitu Clidemia hirta 7,97 persen dari suku Melastomataceae.
Pada areal perkebunan karet dengan ketinggian $104 \mathrm{~m}$ dpl terdapat 10 Jenis gulma daun lebar (broad leaf) dari 9 suku, 1 jenis gulma rerumputan (grasses) dari 1 suku, 1 jenis gulma tekian (cyperaceae) dari 1 suku, dan 3 jenis gulma pakisan (fern) dari 3 Suku.

Berdasarkan morfologinya gulma daun lebar memiliki nilai SDR tertinggi sebesar 63,99\%, gulma rerumputan sebesar 6,44 persen, gulma tekian sebesar 6,01 Persen, dan gulma pakisan (fern) sebesar 23,53 persen. Sehingga, dari hasil nilai SDR maka gulma daun lebar (broad leaf) merupakan gulma dominan.

Berdasarkan daur hidupnya gulma tahunan memiliki nilai SDR 84.21 Persen dengan jumlah gulma sebanyak 12 jenis gulma dan gulma semusim memiliki nilai SDR 15,76 Persen dengan jumlah gulma sebanyak 3 jenis gulma. 
Berdasarkan hasil perbandingan nilai SDR antara $4 \mathrm{~m}$ dpl dan $104 \mathrm{~m}$ dpl maka pada areal perkebunan karet dengan ketinggian $110 \mathrm{~m}$ dpl maka gulma daun lebar dengan siklus hidup tahunan merupakan gulma dominan.

\section{Nilai Koefisien Komunitas}

Dari hasil komunitas gulma pada areal perkebunan karet dengan ketinggian $4 \mathrm{~m}$ dpl, dan $104 \mathrm{~m}$ dpl antara kedua komunitas yang berbeda dengan menggunakan metode yang dikembangkan oleh Sukma (2002).

Nilai koefisien komunitas yang di peroleh antara $4 \mathrm{~m}$ dpl dan $104 \mathrm{~m}$ dpl adalah sebesar 38,36\%. Maka, dapat dikatakan bahwa komunitas gulma berbeda karena nilai $\mathrm{C}<70 \%$.

\section{Faktor-Faktor yang Mempengaruhi Keragaman Komunitas Gulma}

Berdasarkan hasil penelitian, faktor-faktor yang mempengaruhi keragaman komunitas gulma yaitu $\mathrm{pH}$ tanah, kelembaban tanah, dan suhu udara. Kondisi $\mathrm{pH}$ tanah, kelembaban tanah, dan suhu udara di areal tersebut dapat dilihat pada Tabel 3.

Tabel 3. Nilai pH tanah, kelembaban tanah, dan suhu udara di areal perkebunan karet pada ketinggian $4 \mathrm{~m}$ dpl dan $104 \mathrm{~m} \mathrm{dpl}$

\begin{tabular}{lccc}
\hline $\begin{array}{c}\text { Areal } \\
\text { Perkebunan }\end{array}$ & pH Tanah & $\begin{array}{c}\text { Kelembaban } \\
\text { Tanah }\end{array}$ & $\begin{array}{c}\text { Suhu } \\
\text { Udara }\end{array}$ \\
\hline $4 \mathrm{~m} \mathrm{dpl}$ & 6,8 & 28 & 28,7 \\
$104 \mathrm{~m} \mathrm{dpl}$ & 7,2 & 34 & 27,67 \\
\hline
\end{tabular}

Pada areal perkebunan pada ketinggian $4 \mathrm{~m}$ dpl memiliki nilai $\mathrm{pH}$ tanah 6,8 yakni sifatnya asam, nilai kelembaban tanah sebesar $28 \%$ dan nilai suhu udara rata-rata $28,7{ }^{\circ} \mathrm{C}$ dan pada ketinggian $104 \mathrm{~m} \mathrm{dpl}$ memiliki nilai $\mathrm{pH}$ tanah 7,2 yakni sifatnya basa, memiliki nilai kelembaban tanah sebesar 34\% dan suhu udara rata-rata $27,67{ }^{\circ} \mathrm{C}$. Sehingga dapat dikatakan bahwa kondisi areal perkebunan karet tersebut berbeda karena dilihat dari nilai $\mathrm{pH}$ tanah, kelembaban tanah, dan suhu udara yang tidak sama sehingga sifatnya pun berbeda.

\section{Gulma Dominan di Areal Perkebunan Karet Pada Ketinggian Tempat yang Berbeda}

\section{Melastomataceae \\ Clidemia hirta}

Tumbuhan Clidemia hirta (L) termasuk ke dalam ordo Myrtales, suku Melastomataceae, gulma ini mempunyai nama lokal Harendong bulu, buah tinta (Ambon). Tumbuhan ini berasal dari Amerika Selatan, Amerika Tengah, Kepulauan Hindia Barat dan menyebar di seluruh Indonesia. Penyebarannya meliputi $4-1,350 \mathrm{~m}$ dpl. Penyebaran gulma Clidemia hirta oleh burung atau melekat pada bulu binatang, selain itu manusia juga penyebab penyebaran gulma ini.
Gulma ini mempunyai batang berkayu, bulat, berbulu, rapat atau bersisik. Daun tunggal, helai daun berbentuk bulat telur, panjang $2-2-\mathrm{m}$, lebar $1-8 \mathrm{~cm}$, berhadapan, ujung dan pangkal runcing, tepi rata, permukaan daun berbulu dan berwarna hijau. Bunga majemuk, berbulu, ujung meruncing, jumlah bunga 620 buah buni, bulat telur dan berwarna ungu, biji kecil dan berwarna ungu, berakar tunggang.

Clidemia hirta merupakan gulma daun lebar dengan siklus hidup tahunan, gulma yang tangguh dengan perakarannya yang uat dan batangnya yang keras. Tumbuhan ini sering dijumpai di tepi hutan, semak belukar, ditepi jurang, daerah terbuka dan terganggu seperti pinggiran jalan, padang rumput, dan perkebunan.

Berdasarkan nilai SDR, gulma Clidemia hirta merupakan jenis gulma daun lebar yang di temukan pada ketinggian $4 \mathrm{~m}$ dpl dan $104 \mathrm{~m}$ dpl. Akan tetapi nilai SDR tertinggi dapat di jumpai pada areal perkebunan karet pada ketinggian $4 \mathrm{~m}$ dpl $(15,36 \%)$ di bandingkan pada ketinggian $104 \mathrm{~m}$ dpl (7,97\%). GUlma ini mampu beradaptasi pada kondisi daerah dengan kelembaban yang rendah sampai tinggi, dan sarana tumbuh mendukung seperti $\mathrm{pH}$ tanah asam $(6,8)$, suhu udara rendah $(28,7)$ sangat mendukung perbanyakan gulma ini. Biji gulma ini sangat kecil dan halus sehingga mudah diterbangkan angina, mudah melekat pada bulu binatang dan manusia sehingga tinggi tingkat penyebarannya. Gulma ini juga mampu berkembang dengan organ vegetatifnya. Gulma ini merupakan gulma tahunan sehingga dapat berkembang biak secara vegetatif dan generatif. Alat perkembang biakkan inilah yang mampu meningkatkan perkembangbiakan dan penyebarannya.

Utomo (2012), menyatakan bahwa gulma ini tumbuh pada tanah yang lembab atau agak kering, lokasi terbuka atau ternaungi. Hal ini mengindikasikan bahwa gulma ini mampu tumbuh dan menyebar pada kondisi ternaungi pada tingkat kelembaban tanah yang tinggi maupun kondisi terbuka dengan tingkat kelembaban tanah yang rendah.

Kondisi $\mathrm{pH}$ tanah, kelembaban tanah yang sesuai, suhu udara yang rendah serta siklus hidup tahunan memungkinkan gulma ini dapat bertumbuh dan berkembang dengan cepat pada areal perkebunan karet. Proses penyebaran gulma pada setiap ketinggian tempat menunjukan bahwa gulma ini mampu bersaing dan bertahan hidup pada setiap ketinggian tempat asalkan faktor lingkungan mendukung pertumbuhan gulma ini.

\section{Cyperaceae \\ Cyperus kyllingia}

Tumbuhan ini termasuk gulma tekian dengan siklus hidup tahunan dengan nama daerahnya adalah teki udel-udelan. Gulma ini memiliki akar rimpang yang berwarna merah. Teki udel-udelan merupakan rimpang pendek yang beruas teratur. Akar Teki udel-udelan memiliki percabangan yang merayap. Akarnya merupakan sistem percabangan serabut. Berbentuk kecil-kecil seperti benang. Batang Teki udel-udelan ini 
berbentuk segitika yang tajam dengan tinggi batang 0,1 $0,5 \mathrm{~m}$. Warna pada batang Teki udel-udelan ini biasanya berwarna hijau dan tidak memiliki percabangan. Permukaan batang licin dengan arah tumbuh yang tegak lurus dan batangnya merupakan rumput (calmus). Daun Teki udel-udelan ini memiliki panjang 20-35 cm dengan bentuk garis sempi. Lebar daun ini sekitar 2-4 mm, dan juga terdapat daun pembalut yang menutupi pelepah dan bangkol semu yang berbentuk kerucut. Tepi daunnya beringgit dengan pangkal daun yang agak lancip dan ujung daun agak runcing. Bunga Teki udel-udelan ini berbentuk bulat dan berwarna putih. Bunga Teki udeludelan ini biasanya duduk di ujung pucuk dan terdapat banyak bulir. Bungannya terbentuk di ujung batang dan terdiri dari 1-4 kepala bunga yang kompak. Buah Teki udel-udelan ini berbentuk bulat telur dengan panjang 3$4 \mathrm{~mm}$. Buahnya berwarna cokelat muda serta berjerawat halus. Buah ini telettak di tengah-tengah daun dan buah dan buahnya merupakan buah ganda dengan bintik hitam. Bijinya memiliki satu keping biji. Biji keping ini mengan dung endosperm. Bijinya berwarna kehijauan, bentuk bijinya agak pipih dengan permukaan biji yang rata. Setelah masak buah ini akan terlepas dari bakal buahnya.

Habitat gulma ini terdapat didalam limbah dan tempat-tempat berumput. Gulma ini berkembang biak dengan biji atau umbi. Pada beberapa bagian dari umbi tersebut terdapat titik (mata) yang pada saatnya nanti bias muncul atau keluar tunas yang merupakan individu baru dari gulma tersebut. Gulma ini memiliki alat bantu penyebaran dengan rambut. Rambut tersebut membantu biji gulma untuk terbang bersama angina. Gulma ini perkembangbiakkannya sangat cepat serta mampu beradaptasi dengan baik.

Berdasarkan nilai SDR nya, gulma ini ditemukan dengan jumlah banyak pada areal perkebunan karet dengan ketinggian $4 \mathrm{~m}$ dpl dengan nilai SDR nya $11.39 \%$. Gulma tersebut dapat berkembang dan tumbuh dengan baik pada areal perkebunan karet dengan ketinggian $4 \mathrm{~m}$ dpl karena proses perkembangbiakkannya dengan biji atau umbi serta proses penyebarannya yang cepat. Gulma ini juga biasanya tumbuh di daerah yang memiliki $\mathrm{pH}$ tanah asam serta kelembaban tanah yang rendah dan pada areal perkebunan dengan ketinggian $4 \mathrm{~m}$ dpl memiliki jenis tanah yang bersifat asam dan kelembaban tanah yang rendah.

\section{Asteraceae}

\section{Chromolaena odorata} Gulma kirinyu

(Chromolaena odorata L.) termasuk keluarga Asteraceae Compositae. Daunnya berbentuk oval, bagian bawah lebih lebar, makin ke ujung makin runcing. Panjang daun 6-10 cm dan lebarnya 3-6 cm. Tepi daun bergerigi, menghadap ke pangkal. Letak daun juga berhadap-hadapan. Karangan bunga terletak di ujung cabang (terminal). Setiap karangan bunga terdiri atas 20-35 bunga, warna bunga pada saat muda kebiru-biruan, semakin tua menjadi coklat. Krinyu memiliki batang yang tegak, berkayu, ditumbuhi rambut-rambut halus, bercorak garis-garis membujur yang paralel, tingginya mencapai 100-200 cm, bercabang-cabang dan susunan daun berhadapan .

Gulma ini tidak hanya ditemukan di Pulau Jawa tetapi juga ditemukan di seluruh Indonesia seperti di Sumatra, di Kalimantan, di Lombok, Sumbawa dan Flores.

Berdasarkan nilai SDR nya, gulma ini mendominasi pada ketinggian $4 \mathrm{~m}$ dpl di areal perkebunan karet. Gulma yang memiliki nilai SDR 9,86\% ini merupakan gulma daun lebar dengan siklus hidup tahunan. Gulma ini mendominasi diareal perkebunan karet dengan ketinggian $4 \mathrm{~m}$ dpl karena gulma ini mampu berkembang pada tanah yang bersifat asam dengan kondisi tanah yang agak kering.

\section{Wedelia trilobata}

Wedelia adalah salah satu jenis tanaman liar yang hidup di kawasan dengan iklim tropis. Tanaman ini mudah ditemukan di area perkebunan dan persawahan, padang rumput serta di pinggir jalan. Wedelia masuk ke dalam golongan tanaman herba. Tanaman herba adalah tanaman yang tumbuh rendah tidak bisa menjadi tinggi. Wedelia, masih satu keluarga dengan bunga aster.

Wedelia tumbuh dengan panjang antara 18 hingga 24 inchi. Wedelia tumbuh menjalar membentuk suatu bentangan seperti tikar yang menutupi tanah. Daun wedelia berwarna hijau cerah dengan panjang daun antara 1 sampai 3 inchi. Permukaan daun wedelia berbulu dan tepi daun bergerigi. Sebagian besar bentuk daun wedelia adalah lonjong. Bunga wedelia, berwarna kuning cerah, berukuran kecil dengan kelopak bunga melingkar seperti bunga matahari. Putik dan benang sari belingkar penuh di tengah kelopak bunga. Wedelia berkembang biak secara vegetatif alami yaitu dengan cara merunduk. Batang tanaman yang menyentuh tanah akan tumbuh akar dan menjadi tumbuhan baru. Batang wedelia berwarna hijau terang dengan bulu halus yang menutupi seluruh bagian batang.

Tumbuhan wedelia berasal dari Amerika Tengah dan pulau Karibia, tetapi sekarang telah menyebar disemua daerah tropis. Wedelia tumbuh subur di daerah dengan sinar matahari penuh. Semakin banyak sinar matahari, semakin bagus pula bunga wedelia yang tumbuh. wedelia adalah tanaman tropis sehingga dengan subur hidup di daerah tropis. Wedelia juga hidup di negara Hindia Barat, Hawaii, Florida selatan, Amerika Tengah, dan Afrika Barat, terutama pada tanah dengan ketinggian rendah. Tanaman ini lebih suka daerah lembab tetapi juga tahan terhadap kekeringan.

Berdasarkan nilai SDR-nya, gulma wedelia yang merupakan gulma daun lebar dengan siklus hidup tahunan ini ditemukan pada areal perkebunan karet dengan ketinggian $104 \mathrm{~m}$ dpl dengan nilai SDR sebesar $8,64 \%$. Dengan kondisi tanah yang lembah, $\mathrm{pH}$ tanah yang basa serta kelembaban yang tinggi mengakibatkan 
gulma wedelia mampu beradaptasi dan berkembang di areal tersebut.

\section{Thelypteridaceae \\ Cyclosorus aridus}

Tumbuhan ini merupakan gulma yang termasuk dalam golongan pakisan dengan siklus hidup tahunan. Gulma ini berkembangbiakkan dengan spora. Gulma Cyclosorus aridus merupakan gulma yang mempunya potensi cukup besar sebagai gulma. Daya serap terhadap unsur hara $\mathrm{N}, \mathrm{P}$, dan $\mathrm{K}$ hamper sama dengan daya serap lalang dan pertumbuhan memanjang tanaman karet akibat persaingan dengan pakis ini sangat terhambat.

Cyclosorus aridus memiliki akarberbentuk rimpang, akar banyak dan halus, sebagian besar tertanam di dalam tanah, kerapkali bersisik, berwarna coklat sampai kehitam-hitaman. Batang bulat, berwarna kecoklatan, pangkal batang berlekatan dengan rimpang akar, terkadang bersisik lebat dan halus, arah tumbuh batang mendatar, permukaan batang halus. Daun majemuk, permukaan daun kasar, daun steril dengan panjang daun 0,2-2 cm, ujung daun tumpul, tulang daun lateral tidak jelas. Cyclosorus aridus juga memiliki spora, pada paku dewasa, terdapat spora yang dapat hidup dan berkembang pada tempat yang lembab. Spora dihasilkan dari sporangium yang berada di bawah daun fertile, berwarna cokelat.

Berdasarkan nilai SDR nya, Cyclosorus aridus di temukan di areal perkebunan karet pada ketinggian $4 \mathrm{~m}$ dpl dengan nilai SDR 9.79\% dan pada ketinggian $104 \mathrm{~m}$ dpl dengan nilai SDR $11.7 \%$. Cyclosorus aridus merupakan gulma golongan pakisan dengan siklus hidup tahunan yang mampu berkembang dan beradaptasi dengan baik di daerah dengan kondisi kelembaban tanah tinggi serta suhu udara yang tidak terlalu panas sehingga Cyclosorus aridus di temukan lebih banyak pada ketinggian $104 \mathrm{~m}$ dpl karena pada areal tersebut kondisi kelembaban tanah tinggi dan $\mathrm{pH}$ tanah yang bersifat basa serta suhu udara yang lembab. Selain itu, Cyclosorus aridus terdapat lebih banyak di areal dengan ketinggian $104 \mathrm{~m}$ dpl karena pada areal tersebut kehidupan Cyclosorus aridus ternaungi sehingga proses pertumbuhannya lebih cepat dari pada areal dengan ketinggian $4 \mathrm{~m}$ dpl yang kehidupannya langsung terkena sinaran matahari.

\section{Fabaceae}

\section{Centrosema pubescens}

Tumbuhan ini merupakan gulma daun lebar dengan siklus hidup tahunan (perennial) yang akan berkayu ketika usianya lebih dari 18 bulan. Daun beranak tiga; tiap anak daun berbentuk elips, bulat telurmemanjang atau bulat telur-lanset, panjang 1-7 $\mathrm{cm}$ dan lebar 0,5-4,5 cm, dasar daun membulat, ujung daun meruncing tajam, daun berwarna hijau tua, berambut; panjang tangkai daun $5,5 \mathrm{~cm}$. Bunga dapat melakukan fertilisasi sendiri walau belum mekar (cleistogamous), besar, muncul dari tandan aksiler, tiap tandan mendukung 3 - 5 bunga, terdapat 2 daun tangkai; daun kelopak berbentuk lonceng, berukuran1,5 - $3 \mathrm{~mm}$. Buah kering polong, panjang 4-17 cm dan lebar 6-7 mm, pipih, ujung buah meruncing, mengandung hingga 20 biji. Biji berbentuk kecil memanjang, berukuran panjang 4-5 $\mathrm{mm}$ dan lebar 3-4 $\mathrm{mm} \times 2 \mathrm{~mm}$, berwarna coklat kehitaman.

Centrosema berasal dari Amerika Tengah dan Selatan. Tanaman ini merupakan salah satu dari jenis legum yang paling luas penyebarannya di kawasan tropis lembap. Sentro diintroduksi ke kawasan Asia Tenggara dari kawasan tropis Amerika di abad ke 19 atau lebih awal. Saat ini Sentro telah dapt tumbuh alami di dataran-dataran rendah di Jawa.

Centrosema dibudidayakan di daerah tropislembap dengan ketinggian $600-900 \mathrm{~m}$. Tumbuhan ini memerlukan curah hujan tahunan sebesar $1500 \mathrm{~mm}$ atau lebih, namun juga toleran terhadap curah hujan yang lebih rendah, seperti Centrosema yang tumbuh pada ladang-ladang rumput di Afrika hanya mengalami curah hujan sebesar $800 \mathrm{~mm}$. Centrosema tetap dapat tumbuh ketika tempat tumbuhnya tergenang air dan akan bertahan di musim kering yang berlangsung sekitar 3 - 4 bulan, namun tidak untuk masa kekeringan yang lebih panjang. Centrosema tidak dapat tumbuh pada daerah bersuhu rendah. Pertumbuhannya akan menurun ketika suhu turun di bawah $20^{\circ} \mathrm{C}$ dan pertumbuhannya akan menjadi buruk bila suhu turun di bawah $15^{\circ} \mathrm{C}$. Pada kondisi kebekuan yang terjadi bila suhu mencapai $\pm 3^{\circ} \mathrm{C}$ akan menyebabkan daun mati, namun tumbuhan ini dapat tumbuh kembali pada titik-titik tumbuh terlindung dekat tanah. Centrosema merupakan salah satu tanaman polong-polongan yang toleran terhadap naungan dan dapat tetap tumbuh di bawah naungan sebesar $80 \%$. Tumbuhan ini akan tumbuh pada beragam tipe tanah, yaitu dari tanah pasir berhumus hingga tanah liat. Pertumbuhan optimum dapat tercapai bila ditanam pada tanah dengan keasaman relatif, kecukupan aluminium dapat larut (extractable aluminium) yang kurang dari 0.2 meq per $100 \mathrm{~g}$ tanah. Kisaran $\mathrm{pH}$ yang dapat ditoleransi adalah 4,5-8,0, namun kisaran $\mathrm{pH}$ optimum yang dapat mendukung pertumbuhan nodul adalah 5,5-6,0. Meskipun centro cukup toleran pada kadar Mn di tanah yang tinggi, namun ada keterkaitan antara keracunan Mn dengan tingkat $\mathrm{pH}$ rendah pada tanah-tanah asam, maka hal ini dapat diperbaiki dengan memperhatikan batasan kadar $\mathrm{Mn}$ dan $\mathrm{pH}$ tanah. Centrosema dapat tumbuh dengan baik bersama-sama spesies tumbuhan lain di padang-padang rumput atau sebagai penutup tanah pada areal tanaman-tanaman pertanian. Pada daerah tropis lembap, tanaman polong-polongan yang dipilih untuk ditanam baik di tanah-tanah subur maupun kurang subur telah memanfaatkan jasa centro. Tanah yang kekurangan mineral dapat dipulihkan dengan menginokulasikan benih-benih dengan Bradyrhizobium, dan centro akan menunjukkan pertumbuhan dan produksi yang baik untuk tumbuh di semua tipe tanah.

Berdasarkan nilai SDR nya, Centrosema pubescens ditemukan pada areal perkebunan karet dengan ketinggian $104 \mathrm{~m}$ dpl. Areal tersebut memiliki $\mathrm{pH}$ tanah yang bersifat basa dengan kelembaban tanah yang tinggi, kondisi areal yang lembab memungkinkana 
gulma Centrosema pubescens untuk beradaptasi dan berkembang.

\section{Acanthaceae \\ Mimosa pudica}

Putri malu atau Mimosa pudica adalah perdu pendek anggota suku polong-polongan yang mudah dikenal karena daun-daunnya yang dapat secara cepat menutup/layu dengan sendirinya saat disentuh. Walaupun sejumlah anggota polong-polongan dapat melakukan hal yang sama, putri malu bereaksi lebih cepat daripada jenis lainnya. Kelayuan ini bersifat sementara karena setelah beberapa menit keadaannya akan pulih seperti semula.

Mimosa pudica merupakan herba tegak dan agak rebah. Jika tumbuhan ini merambat pada pagar, maka tingginya dapat mencapai $\pm 2 \mathrm{~m}$. Namun, ada juga yang merayap di permukaan tanah. Mimosa pudica memiliki bunga majemuk berbentuk bola berwarna merah muda atau ungu muda. Bunga majemuk ditopang oleh tangkai yang panjang berwarna hijau atau kecoklatan dengan permukaan yang ditumbuhi bulu halus. Batangnya berbentuk silindris, berkayu. Batang ada yang berwarna hijau da nada yang berwarna coklat kemerahan. Permukaan batang tertutup oleh bulu-bulu halus berwarna putih. Pada batang juga terdapat duri, tepatnya tumbuh pada bagian bawah dari pangkal daun majemuk. Memiliki daun majemuk yang terdiri dari 2 atau 4 helai daun, setiap helai terdapat 15 - 20 pasang anak daun. Memiliki buah polong yang berambut. Tumbuhan yang daun majemuknya terdiri dari 2 helai daun akan memiliki buah yang berisi 1-2 biji.

Berdasarkan nilai SDR nya, gulma ini ditemukan di areal perkebunan karet pada ketinggian $4 \mathrm{~m} \mathrm{dpl}$ dengan nilai SDR sebesar 9,51\% dan mampu beradaptasi dan berkembang di daerah yang memiliki kelembaban tanah rendah sehingga kondisi tanahnya kering.

\section{Selaginellaceae}

\section{Selaginella doederleinii hieron}

Tanaman Paku cakar ayam (Selaginella doederleinii Hieron) adalah tumbuhan yang memiliki batang tegak dengan tinggi sekitar $15-35 \mathrm{~cm}$ dan akarnya keluar pada percabangan. Tanaman paku cakar ayam memiliki daun yang kecil-kecil dengan panjang 4$5 \mathrm{~mm}$, lebar $2 \mathrm{~mm}$, berbentuk jorong dengan ujung meruncing serta pangkal yang rata. Salah satu ciri khas lainnya adalah dari warna daun, di mana di bagian atas hijau tua sedangkan bagian bawah hijau muda. Daun tersusun di kiri-kanan batang induk sampai ke percabangannya yang menyerupai cakar ayam dengan sisik-sisiknya. Paku cakar ayam mempunyai habitus terna, merayap, dan sedikit tegak. Batang bulat, liat, bercabang-cabang menggarpu, tanpa pertumbuhan sekunder, dan putih kecoklatan. Akarnya serabut dan muncul dari batang yang berdaun dan berwarna coklat kehitaman.

Berdasarkan nilai SDR nya, gulma ini di temukan dengan jumlah banyak yakni nilai SDR nya sebesar $8.96 \%$ pada areal perkebunan karet dengan ketinggian $104 \mathrm{~m}$ dpl. Gulma ini mampu tumbuh dan berkembang dengan cepat di areal tersebut karena perkembangbiakkannya dengan spora sehingga apabila tertiup angina spora akan terbang dan tersebar kemana saja.

\section{Faktor-Faktor Yang Mempengaruhi Keragaman Komunitas Gulma}

Keragaman gulma yang terdapat pada areal perkebunan karet untuk kedua areal penelitian relatif berbeda. Berdasarkan nilai koefisien komunitas gulma ternyata komunitas gulma antara areal perkebunan karet dengan ketinggian $4 \mathrm{~m}$ dpl dengan $104 \mathrm{~m} \mathrm{dpl} \mathrm{berbeda}$ nyata atau tidak seragam karena nilai $\mathrm{C}$.

Berdasarkan nilai koefisien komunitas gulma yang di peroleh yaitu sebesar $38.36 \%$, ternyata komunitas gulma pada areal perkebunan karet antara ketinggian $4 \mathrm{~m}$ dpl dan $104 \mathrm{~m} \mathrm{dpl}$ berbeda nyata atau tidak seragam karena nilai $\mathrm{C}<70 \%$. Maka cara pengendalian gulma yang dianjurkan untuk kedua areal pun tidak sama.

Pada areal perkebunan karet untuk ketinggian 4 m dpl dan $104 \mathrm{~m}$ dpl, gulma daun lebar dengan siklus hidup tahunan lebih mendominasi di areal ini. Gulma daun lebar memiliki kemampuan mengambil unsur hara, air dan cahaya lebih banyak dari gulma rerumputan, tekian, dan pakisan. Dengan demikian, gulma daun lebar memiliki daya kompetisi yang tinggi dengan gulma lain seperti gulma rerumputan, tekian, dan pakisan sehingga gulma daun lebar mampu tumbuh dan berkembang serta mendominasi di areal perkebunan karet Awaya, selain itu, gulma daun lebar juga memiliki kemampuan beradaptasi yang tinggi baik pada ketinggian $4 \mathrm{~m}$ dpl maupun pada ketinggian $104 \mathrm{~m}$ dpl. Semakin tinggi ketinggian, maka gulma daun lebar semakin mampu menyesuaikan diri dengan lingkungan tumbuhnya. Jika ketinggian tempat bertambah maka suhu udara akan semakin rendah dan kelembaban tanah akan semakin tinggi sehingga gulma daun lebar mampu beradaptasi dengan cepat. Selain itu, gulma daun lebar memiliki kemampuan beradaptasi yang tinggi di tanah yang bersifat masam, sehingga, gulma berdaun lebar terlihat dominan pada kedua areal perkebunan karet tersebut namun yang lebih banyak populasinya terdapat di areal dengan ketinggian $104 \mathrm{~m}$ dpl dan memiliki nilai $\mathrm{pH}$ tanah 6,8.

Pada areal perkebunan karet di ketinggian $4 \mathrm{~m}$ dpl suhunya lebih tinggi dari pada di ketinggian $104 \mathrm{~m}$ dpl. Semakin rendah suatu daerah, maka semakin panas suhunya dan sebaliknya semakin tinggi suatu daerah maka semakin dingin suhunya. Perbedaan ketinggian ini menyebabkan keanekaragaman penyebaran hewan dan tumbuhan berbeda pada semua wilayah. Dengan demikian, pada ketinggian $4 \mathrm{~m}$ dpl dan $104 \mathrm{~m} \mathrm{dpl}$ terlihat jelas suhu udara pada setiap ketinggian berbeda. Semakin tinggi ketinggian tempat, suhu udaranya semakin rendah dan semakin rendah ketinggian tempat, suhu udaranya semakin tinggi. Hal ini mempengaruhi 
komunitas gulma. Gulma akan cenderung berbeda pada setiap ketinggian tempat karena terjadi perbedaan dan pergeseran jenis gulma pada setiap ketinggian tempat.

Kelembaban tanah merupakan salah satu faktor yang mempengaruhi keragaman komunitas gulma. Pada ketinggian $104 \mathrm{~m}$ dpl kelembaban tanah lebih tinggi di bandingkan pada ketinggian $4 \mathrm{~m}$ dpl. Pada areal perkebunan karet dengan ketinggian $104 \mathrm{~m}$ dpl memiliki nilai kelembaban tanah 34 dan pada ketinggian $4 \mathrm{~m}$ dpl memiliki nilai kelembaban tanah 28. Kelembaban tanah berhubungan dengan jumlah vegetasi tanaman. Berdasarkan hasil penelitian, semakin tinggi ketinggian tempat maka semakin berbeda vegetasi jenis gulma. Semakin rendah ketinggian tempat gulma rerumputan semakin banyak dan semakin tinggi ketinggian tempat gulma daun lebar semakin banyak. Begitu juga dengan kelembaban tanah, gulma rerumputan lebih dominan pada kelembaban tanah rendah dan gulma berdaun lebar lebih dominan pada kelembaban tinggi. Perbedaan kelembaban tanah memungkinkan perbedaan komunitas gulma. Ketinggian tempat juga sangat berpengaruh terhadap tingkat kelembaban tanah suatu komunitas gulma.

Keragaman suatu komunitas gulma, pergeseran serta perbedaan komunitas gulma pada setiap ketinggian tempat sangat di pengaruhi oleh faktor lingkungan antara lain ketinggian tempat, suhu udara, kelembaban tanah, $\mathrm{pH}$ tanah, cara perbanyakan dan penyebaran gulma.

\section{Kajian Keragaman dan Dominasi Gulma Dengan Kebijakan Pengendalian}

Keragaman komunitas vegetasi gulma untuk setiap tempat dalam hal ini perbedaan ketinggian tempat relatif berbeda. Berdasarkan hasil pengamatan di lapangan, pada ketinggian $4 \mathrm{~m}$ dpl di temukan gulma berdaun lebar 3 jenis, gulma rereumputan 3 jenis, gulma tekian 3 jenis, dan gulma pakisan 2 jenis. Pada ketinggian $104 \mathrm{~m}$ dpl di temukan gulma berdaun lebar 10 jenis, gulma rerumputan 1 jenis, gulma tekian 1 jenis, dan gulma pakisan 3 jenis. Sesuai dengan hasil perhitungan nilai koefisien komunitas gulma maka gulma antara ketinggian $4 \mathrm{~m}$ dpl dan $104 \mathrm{~m}$ dpl itu berbeda nyata karena nilai koefisien komunitasnya $\mathrm{C}$ $<70 \%$ sehingga tindakan pengendalian yang di anjurkan untuk kedua areal perkebunan karet berbeda. Selain itu, gulma yang mendominasi areal perkebunan karet baik pada ketinggian $4 \mathrm{~m}$ dpl maupun $104 \mathrm{~m} \mathrm{dpl}$ adalah jenis gulma berdaun lebar dengan siklus hidup tahunan.

Pada ketinggian $4 \mathrm{~m}$ dpl, gulma yang mendominasi areal tersebut adalah gulma berdaun lebar yaitu Clidemia hirta dari suku Melastomataceae dan

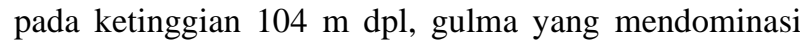
areal tersebut adalah gulma pakisan yaitu Cyclosorus aridus dari suku Thelypteridaceae.

Adanya keragaman dan dominasi pada perkebunan karet tersebut memberi petunjuk bahwa pengendalian gulma perlu di perhatikan dari segi pertimbangan aspek ekonomi dan ekologisnya. Dalam pengusaha tanaman karet, saran pengendalian gulma harus ditunjuk untuk memanilisir kerugian dan gangguan yang ditimbulksn oleh gulma sekecil mungkin agar pertumbuhan dan produksi tanaman tidak terganggu. Dengan memperhatikan jenis-jenis gulma, aspek lingkungan, biaya, tenaga kerja serta keuntungan dan kerugian yang ditimbulkan oleh pengendalianpengendalian gulma. Sehingga, perlu di terapkan suatu pengendalian gulma yang terpadu.

Pengendalian gulma secara terpadu adalah dengan cara menggabungkan beberapa metode secara tepat untuk menekan perkembangan populasi gulma dan memperthankan gulma pada tingkat yang lebih tinggi yang tidak merugikan dengan mempertimbangkan kelestarian lingkungan.

Pada metode pengendalian terpadu, ada dua tujuan yang dicapai, yaitu pengendalian gulma dilakukan tidak hanya mutlak dilakukan dengan satu metode melainkan dengan gabungan beberapa metode yang mungkin secara tepat dan metode terpadu di tunjukkan untuk menekan populasi gulma bukan untuk memberantas atau memusnahkan gulma secara total.

Dari dominasi jenis gulma yang terdapat di areal perkebunan karet tersebut, maka pengendalian gulma harus dilakukan terutama terhadap gulma penting dan dominan. Tindakan pengendalian gulma secara total cenderung merusak ekologi. Misalnya, mengakibatkan gundulnya permukaan tanah sehingga dapat terjadi erosi dan penggunaan herbisida secara berlebihan dapat mengakibatkan pencemaran lingkungan.

Gulma tertentu yang penting untuk dikendalikan pada areal perkebunan karet dengan ketinggian $4 \mathrm{~m}$ dpl dan $104 \mathrm{~m}$ dpl adalah Clidemia hirta, Cyperus kyllingia, Chromolaena odorata, Cyclosorus aridus, Selaginella doederleinii hieron, dan Wedelia trilobata. Gulmagulma tersebut perlu di kendalikan karena populasinya yang banyak akan memberi efek persaingan yang besar dengan tanaman.

\section{Rumusan Pengendalian Gulma}

Dalam pengusaha perkebunan karet disarankan pengendalian gulma yang bertujuan untuk menekan kerugian dan gangguan yang ditimbulkan oleh gulma hingga sekecil mungkin agar pertumbuhan dan produksi dari perkebunan karet tidak terganggu. Pada daerah penelitian ini sudah tidak pernah di lakukan manajemen budidaya karet. Untuk itu di sarankan agar pengendalian gulma dapat dilakukan pada areal perkebunan karet Negeri Liang Kecamatan Teluk Elpaputih Kabupaten Maluku Tengah.

\section{Metode Pengendalian Gulma Pada Areal Perkebunan Karet}

\section{Pengendalian Mekanis}

Gulma yang berkembangbiak dengan rhizome, stolon, dan umbi disarankan pengendalian gulma dengan cara pengolahan tanah. Pengolahan tanah ini 
biasanya dikerjakan pada saat musim kemarau, dilakukan selama dua kali dengan interval waktu 2-3 minggu agar rhizome dan umbi dapat kering, sedangkan untuk gulma yang berkembang biak dengan biji dan pangkal batang, pengendalian yang disarankan yaitu dengan cara eradikasi.

Pengendalian gulma dengan cara mekanis juga dapat dilakukan dengan tenaga manusia atau menggunakan alat-alat mekanisasi. Secara mekanis disarankan pengendalian di tanaman karet adalah membabat dengan menggunakan sabit, parang atau cangkul, mencabut dan membersihkan gulma dengan tangan. Prinsip dari metode ini adalah merusak perakaran yang rimpang maupun bagian gulma yang ada diatas tanah sehingga gulma mati. Waktu yang tepat untuk pelaksanaan disesuaikan dengan keadaan pertumbuhan gulma yaitu masih sebelum berbunga dilakukan pembabatan. Pembabatan pada gulma bertujuan untuk mematikan gulma yang masih muda dan mencegah pertumbuhan biji. Cara pembabatan ini dianggap efektif untuk gulma yang berkemang biak secara generative, namun disisi lain pengendalian gulma secara mekanik memiliki kerugian yaitu membutuhkan banyak tenaga kerja dan waktu pelaksanaannya yang lama.

\section{Pengendalian Kultur Teknis}

Pengendalian gulma dengan mulsa yaitu daundaun karet yang sudah kering pada perkebunan karet dibiarkan di permukaan tanah yang ditumbuhi gulma dengan tertutupnya permukaan tanah tersebut gulma tidak akan mendapatkan sinar matahari yang cukup sehingga pertumbuhannya akan terhambat.

\section{Pengendalian Kimiawi}

Pengendalian secara kimiawi adalah pengendalian dengan menggunakan herbisida yang mengandung persenyawaan kimia yang dapat mematikan atau menekan pertumbuhan gulma. Gulma yang berkembang biak dengan spora disarankan pengendaliannya menggunakan herbisida.

\section{Pengendalian Gulma Terpadu}

Pengendalian gulma pada areal pertanaman karet untuk areal perkebunan karet pada ketinggian $4 \mathrm{~m} \mathrm{dpl}$ dan $104 \mathrm{~m}$ dpl belum dilakukan tindakan pengendalian dengan baik, untuk itu perlu dilakukan metode pengendalian gulma secara terpadu.

Pengendalian ini merupakan gabungan dari beberapa pengendalian mekanis, kultur teknis, dan juga kimiawi yang secara tepat untuk menekan populasi gulma dan mempertahankannya pada tingkat yang tidak merugikan dengan mempertimbangkan kelestarian lingkungan (Syawal, 2011).

Menekan populasi gulma dan mempertahankan pada tingkat yang tidak merugikan berarti mengendalikan atau mengontrol gulma agar tumbuh pada tingkat kerapatan tertentu serta mengendalikan jenis gulma yang tumbuh agar hanya terdiri dari spesiesspesies yang tidak merugi.

\section{KESIMPULAN}

1. Jenis gulma dominan pada areal perkebunan karet pada ketinggian $4 \mathrm{~m}$ dpl adalah gulma Clidemia hirta dan jenis gulma dominan pada ketinggian 104 $\mathrm{m}$ dpl adalah gulma Cyclosorus aridus.

2. Jenis-jenis gulma pada perkebunan karet pada ketinggian $4 \mathrm{~m}$ dpl berbeda dengan pada ketinggian $104 \mathrm{~m}$ dpl.

3. Semakin tinggi ketinggian tempat pada areal perkebunan karet maka semakin banyak jenis gulma yang ditemukan.

\section{UCAPAN TERIMA KASIH}

Terima kasih kepada PT. Perkebunan Nusantara XIV Awaya, Maluku yang telah membantu dalam penelitian ini.

\section{DAFTAR PUSTAKA}

Istiawan, N.D. dan D. Kastono. 2018. Pengaruh ketinggian tempat tumbuh terhadap hasil dan kualitas minyak cengkih (Syzygium aromaticum L.) Merr. \& Perry.) di Kecamatan Samigaluh, Kulon Progo. Jurnal Vegetalika 8: 27-41. DOI: 10.22146/veg. 35744

Kilkoda, A.K., T. Nurmala, dan D. Widayat. 2015. Pengaruh keberadaan gulma (Ageratum conyzoides dan Boreria alata) terhadap pertumbuhan dan hasil tiga ukuran varietas kedelai (Glycine max L. Merr) pada percobaan pot bertingkat. Jurnal Kultivasi 14: 1-9. DOI: 10.24198/kltv.v14i2.12072

Ngatiman, dan M. Fajri. 2018. Teknik pengendalian gulma terhadap pertumbuhan Shorea Leprosula Miq. di KHDTK Labanan, Berau, Kalimantan Timur. Jurnal Penelitian Ekosistem Dipterokarpa 4: 35-48. DOI: 10.20886/jped.2018.4.1.35-48

Nurnasari, E. dan Djumali. 2010. Pengaruh kondisi ketinggian tempat terhadap produksi dan mutu tembakau Temanggung. Buletin Tanaman Tembakau, Serat \& Minyak Industri 2: 45-59. DOI: 10.21082/bultas.v2n2.2010.45-59

Oldeman, L.R. 1975. The Agroclimatic Map of Java dan Madura. Bogor. Contribution from The Central Researth Institute for Agriculture.

Palijama, W., J. Riry dan A.Y. Wattimena. 2012. Komunitas gulma pada pertanaman pala (Myristica fragrans H.) belum menghasilkan dan menghasilkan di Desa Hutumuri Kota Ambon. Agrologia, Jurnal Ilmu Budidaya Tanaman 1: 134-142. DOI: 10.30598/a.v1i2.289

Prayogo, D.P., H.T. Sebayang, dan A. Nugroho. 2017. Pengaruh pengendalian gulma pada pertumbuhan dan hasil tanaman kedelai (Glycine max L. 
Merril) pada berbagai sistem olah tanah. Jurnal Produksi Tanaman 5: 24-32.

PTPN XIV. 2014. Laporan Manajemen Tahunan. Makassar.

Riry, J. 2008. Mengenal Gulma dan Pengelolaannya di Indonesia. Bogor: CV D'sainku Advertising.

Sastroutomo, S. 1988. Ekologi Gulma. Jakarta: PT. Gramedia Pustaka Utama.

Sukman, Y. 2012. Gulma dan Teknik Pengendaliannya. Jakarta: PT. Raja Grafindo Persada.

Syawal, Y. 2012. Dasar-Dasar Pengendalian Gulma. Palembang: Penerbit Universitas Sriwijaya Fakultas Pertanian.
Tanasale, V. 2010. Komunitas Gulma Pada Pertanaman Gandaria Belum Menghasilkan dan Menghasilkan Pada Keringgian Tempat Yang Berbeda. Tesis. UGM, Yogyakarta.

Taulu, L.A. 2014. Pengaruh Ketinggian Tempat Terhadap Perkembangan Organisme Pengganggu Tanaman (OPT) Pada Tanaman Padi Di Sulawesi Utara. Prosiding Balai Pengkajian Teknologi Pertanian Sulawesi Utara. Manado.

Utomo, S. 2012. Artikel: Klasifikasi Gulma Pada Tanggal 22 September 2012. Diakses dari http://Sarriutomoku.Blogspot.Com/2012/Pengerti an-Gulma-Kelapa-Sawit.html. Tanggal 25 November 2018. 